\title{
UJI AKTIVITAS ANTIBAKTERI FRAKSI n-HEKSAN KULIT BUAH NAGA MERAH (Hylocereus polyrhizus Britton \& Rose) TERHADAP BAKTERI Staphylococcus aureus ATCC 25923
}

\author{
Sri Amalia*), Sri Wahdaningsih, Eka Kartika Untari \\ Department of Pharmacy, Faculty of Medical, Universitas Tanjungpura, Pontianak Indonesia \\ *)Email: melly.amalia14@yahoo.com
}

\begin{abstract}
ABSTRACK
Inappropiate antibiotic use was one of the main reason that caused pathogenic microorganism resistance, leads to ineffective treatment. One of those resistance bacteria is Staphylococcus aureus. The research for discovering new antibiotics can help with this issue. The peel of red dragon fruit (Hylocereus polyrhizus) is one of the plants that has antibacterial compounds. The aim of this research is to prove and determine the minimum inhibitory concentration (MIC) value of n-hexane fraction of red dragon fruit's peel againts Staphylococcus aureus ATCC 25923. The peel was maserated with chloroform, then fractinated by $n$-hexane. Futhermore, the antibacterial properties of the fraction was tested using Disc Diffusion (Kirby-Bauer) methode with 40, 20 dan $10 \mathrm{mg} / \mathrm{mL}$ concentrations. Ampisilin used as control positive. Based on the phytochemical screening of the fraction, the n-hexane fraction of the dragon fruit's peel contain triterphenoid, steroid and alkaloid. Clear zones produced by $40 \mathrm{mg} / \mathrm{mL}$ is $12,80 \mathrm{~mm}$ and for $20 \mathrm{mg} / \mathrm{mL}$ is $11,17 \mathrm{~mm}$. Wherea concentration $10 \mathrm{mg} / \mathrm{mL}$ didn't show any inhibitory zone. According to this reasearch, the MIC value of the fraction is $20 \mathrm{mg} / \mathrm{mL}$.
\end{abstract}

Keywords: Antibacterial, n-Hexane fraction of dragon fruit's peel, Staphylococcus aureus ATCC 25923.

\section{PENDAHULUAN}

\section{Latar Belakang}

Antibiotik merupakan senyawa yang digunakan untuk mengatasi infeksi bakteri. Permasalahan penggunaan antibiotik saat ini dalam pengobatan adalah resistensi antibiotik. Penggunaan antibiotik yang tidak sesuai menyebabkan mikroorganisme pathogen menjadi resisten sehingga pengobatan infeksi menjadi tidak efektif. Salah satu bakteri yang mengalami resistensi adalah Staphylococcus aureus. Bakteri Staphylococcus aureus terdapat pada saluran pernapasan atas, tangan, dan rambut. Bakteri ini dapat menyebabkan keracunan dan kerusakan pada kulit (Melliawati, 2009).

Penemuan senyawa antibiotik baru yang belum mengalami resistensi menjadi salah satu solusi alternatif untuk mengatasi permasalahan ini. Senyawa tersebut dapat diperoleh dari tanaman. Tanaman memiliki kandungan senyawa yang berpotensi sebagai antibakteri dengan mekanisme aksi yang baru dan belum mengalami resistensi. Tanaman yang memiliki aktivitas antibakteri salah satunya adalah buah naga merah (Hylocereus polyrhizus Britton \& Rose).

Buah naga merah merupakan buah dari suku Cactaceae, yang mulai banyak dikonsumsi di Indonesia. Buah naga merah secara berkala dapat mencegah dan mengobati osteoporosis, hipertensi, diabetes dan menurunkan kolesterol (Warisno, 2010).
Penelitian mengenai khasiat buah naga merah juga telah banyak dilakukan. Buah naga merah memiliki khasiat sebagai antihepatotoksik (Latif dkk, 2006), antioksidan (Wu, 2000) dan hipokolesterole-mik (Khalili, 2010). Pemanfaatan buah naga merah hanya terpaku pada daging buahnya, sedangkan kulitnya belum dimanfaatkan secara optimal. Penelitian membuktikan bahwa fraksi n-heksan yang memiliki kedekatan famili dengan buah naga merah mempunyai aktivitas antibakteri pada Staphylococcus aureus. Penelitian Nurmahani juga membuktikan bahwa ekstrak n-heksan, kloroform dan etanol kulit buah naga merah memiliki aktivitas antibakteri pada bakteri Gram positif dan Gram negatif (Nurmahani, 2012).

Penelitian mengenai aktivitas antibakteri pada kulit buah naga merah hanya sebatas proses ekstraksi, sehingga perlu dilakukan penelitian lebih lanjut hingga proses fraksinasi. Penelitian ini diharapkan dapat memberikan informasi mengenai potensi kulit buah naga merah sebagai alternatif pengobatan antibakteri alami pada Staphylococcus aureus.

\section{METODOLOGI}

\section{A. Bahan dan Alat}

Bahan yang digunakan pada penelitian ini yaitu kulit buah naga merah, kloroform, n-heksan, dimethylsulfoksida (DMSO), aquades, ampisilin, Mueller Hinton Agar (MHA), dan Mc Farland 0,5. Alat yang digunakan yaitu corong pisah, rotary 
evaporator, jarus ose, cawan petri, dan jangka sorong.

\section{B. Pembuatan Fraksi n-Heksan Kulit Buah Naga Merah}

Sampel yang digunakan adalah kulit dari buah naga merah yang didapat di Perkebunan Petani Mekar Sari Kecamatan Segedong, Kabupaten Pontianak, Provinsi Kalimantan Barat. Kulit tersebut dicuci dengan air mengalir, kemudian dirajang dan disortasi basah. Setelah itu dikeringkan dan diblender hingga menjadi simplisia. Simplisia kemudian dimaserasi menggunakan pelarut kloroform selama 7 hari. Ekstrak kloroform kemudian difraksinasi caircair dengan pelarut n-heksan. Fraksi n-heksan kemudian dipekatkan menggunakan rotary evaporator dan dilakukan skrining firokimia (alkaloid, tanin, polifenol, triterpenoid, steroid, saponin dan flavonoid).

\section{Pembuatan Variasi Konsentrasi Fraksi n- Heksan Kulit Buah Naga Merah}

Larutan stok fraksi n-heksan kulit buah naga merah adalah $80 \mathrm{mg} / \mathrm{mL}$, dengan melarutkan sebanyak $800 \mathrm{mg}$ fraksi n-heksan pada DMSO 10\% dalam $10 \mathrm{~mL}$ aquades. Kemudian dilakukan pengenceran bertingkat untuk membuat konsentrasi 40, 20 dan $10 \mathrm{mg} / \mathrm{mL}$.

\section{Pengujian Aktivitas Antibakteri Fraksi n- Heksan Kulit Buah Naga Merah}

Aktivitas antibakteri sampel dilakukan pada bakteri Staphylococcus aureus ATCC 25923 yang diperoleh dari Departemen Mikrobiologi Fakultas Kedokteran Universitas Indonesia. Pengujian menggunakan metode Disc diffusion (Kirby Bauer). Bakteri dari media peremajaannya diinokulasikan pada media MHA yang telah padat. Kemudian diteteskan $20 \mu \mathrm{L}$ fraksi n-heksan kulit buah naga merah dengan berbagai konsentrasi pada cakram kertas $(6 \mathrm{~mm})$, kemudian diinkubasi dalam inkubator selama 24 jam, setelah itu diukur diameter zona hambat atau zona bening dengan jangka sorong (ICMR, 2009). Kontrol positif yang digunakan

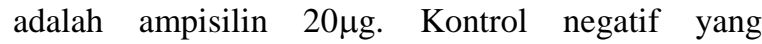
digunakan adalah DMSO 1dan 10\%.

\section{HASIL DAN PEMBAHASAN}

\section{A. Skrining Fitokimia}

Skrining fitokimia telah dilakukan terhadap fraksi n-heksan kulit buah naga merah. Hasil penelitian menunjukkan bahwa fraksi n-heksan kulit buah naga merah menunjukkan hasil positif terhadap pemeriksaan alkaloid, triterpenoid dan steroid. Sedangkan senyawa fenolik, tanin, flavonoid dan saponin menunjukkan hasil negatif. Hasil skrining terdapat pada Tabel 1 .

Tabel 1. Hasil skrining fitokimia Fraksi n-Heksan Kulit Buah Naga Merah

\begin{tabular}{|l|l|l|}
\hline Pemeriksaan & Reagen & Hasil \\
\hline \multirow{3}{*}{ Alkaloid } & Mayer & + \\
\cline { 2 - 3 } & Dragendrof & + \\
\cline { 2 - 3 } & Wagner & + \\
\hline Polifenol & $\mathrm{FeCl}_{3} 1 \%$ & - \\
\hline Flavonoid & $\mathrm{Mg}, \mathrm{HCl}$ & - \\
\hline Saponin & $\mathrm{Air}, \mathrm{HCl}$ & - \\
\hline \multirow{2}{*}{ Steroid/Triterpenoid } & $\begin{array}{l}\text { Lieberman } \\
\text { Burchard }\end{array}$ & - \\
\hline Tanin & $\mathrm{FeCl}_{3} 5 \%$ & - \\
\hline
\end{tabular}

Ket: (+) positif : mengandung golongan senyawa;

$(-)$ negatif: tidak mengandung golongan senyawa.

\section{B. Uji Aktivitas Antibakteri}

Penentuan aktivitas antibakteri fraksi n-heksan kulit buah naga merah dilakukan dengan metode disc diffusion Kirby-Bauer yaitu penentuan sensivitas bakteri dengan suatu zat tertentu yang kemungkinan memiliki aktivitas antibakteri dengan menggunakan cakram kertas.

Hasil uji aktivitas fraksi n-heksan kulit buah naga merah terhadap Staphylococcus aureus adalah konsentrasi 40 dan $20 \mathrm{mg} / \mathrm{mL}$ memiliki aktivitas antibakteri, sedangkan $10 \mathrm{mg} / \mathrm{mL}$ tidak memiliki aktivitas antibakteri karena tidak terdapat zona bening disekitar cakramnya. Rata-rata zona hambat fraksi n-heksan kulit buah naga merah dengan konsentrasi $40 \quad \mathrm{mg} / \mathrm{mL}$ adalah $12,8 \mathrm{~mm}$ dan konsentrasi $20 \mathrm{mg} / \mathrm{mL}$ adalah $11,17 \mathrm{~mm}$. Kontrol negatif DMSO dengan berbagai konsentrasi terbukti tidak memiliki aktivitas antibakteri, sehingga dapat dipastikan aktivitas antibakteri yang dihasilkan murni dari fraksi n-heksan kulit buah naga merah tanpa pengaruh dari pelarutnya. Kontrol positif ampisilin memiliki rata-rata zona hambat sebesar $32,70 \mathrm{~mm}$ terhadap Staphylococcus aureus. Hasil pengujian aktivitas antibakteri fraksi n-heksan kulit buah naga merah, DMSO dan ampisislin terdapat pada tabel 2.

Tabel 2. Hasil Pengujian Antibakteri Fraksi nHeksan Kulit Buah Naga Merah Terhadap Staphylococcus aureus

\begin{tabular}{|c|c|c|c|c|}
\hline \multirow{2}{*}{$\begin{array}{c}\text { Konsentrasi } \\
\text { ppm }\end{array}$} & \multicolumn{2}{|c|}{ Zona Hambat (mm) } & \multirow{2}{*}{$\begin{array}{c}\text { Rata-rata } \\
\text { (mm) }\end{array}$} \\
\cline { 2 - 4 } & I & II & III & \\
\hline 20.000 & 14,50 & 10 & 9 & 11,17 \\
\hline 40.000 & 12 & 11,40 & 15 & 12,80 \\
\hline
\end{tabular}




\begin{tabular}{|c|c|c|c|c|}
\hline 10.000 & - & - & - & - \\
\hline Ampicilin & 28,70 & 33,40 & 36 & 32,70 \\
\hline DMSO 10\% & - & - & - & - \\
\hline DMSO 1\% & - & - & - & - \\
\hline
\end{tabular}

Ket: - = tidak terdapat zona hambat

Berdasarkan tabel 2 dapat ditentukan bahwa konsentrasi hambat minimum fraksi n-heksan kulit buah naga merah terhadap Staphylococcus aureus adalah $20.000 \mathrm{ppm}$ atau $20 \mathrm{mg} / \mathrm{mL}$ dengan zona hambat rata-rata $11,17 \mathrm{~mm}$. Konsentrasi $20 \mathrm{mg} / \mathrm{mL}$ dinyatakan sebagai KHM karena merupakan konsentrasi terkecil yang masih dapat menghasilkan zona hambat.

Rata-rata zona hambat dari kedua konsentrasi fraksi n-heksan kulit buah naga merah, maka zona hambat yang dihasilkan semakin besar. Zona hambat yang dihasilkan oleh konsentrasi $40 \mathrm{mg} / \mathrm{mL}$ dinyatakan peka sebagai antibakteri karena Departemen Kesehatan menyebutkan bahwa mikroba dinyatakan peka terhadap antibakteri asal tanaman apabila mempunyai ukuran diameter daya hambatannya (daerah bening) 12-24 mm (Depkes RI, 1988). Staphylococcus aureus merupakan bakteri Gram positif. Bakteri Gram positif memiliki kepekaan terhadap antibakteri lebih baik dibandingkan Gram negatif karena adanya perbedaan struktur dinding sel. Struktur dinding sel bakteri Gram negatif relatif lebih kompleks, berlapis tiga yaitu lapisan luar yang berupa lipoprotein, lapisan tengah yang berupa lipopolisakarida dan lapisan dalam berupa peptidoglikan. Sedangkan struktur dinding sel mikroba gram positif relatif lebih sederhana sehingga memudahkan senyawa antimikroba untuk masuk ke dalam sel dan menemukan sasaran untuk bekerja (Zuhud dkk, 2001).

Tabel 3. Hasil Uji Kruskal Wallis Zona Hambat Fraksi n-Heksan Kulit Buah Naga Merah terhadap Staphylococcus aureus

\begin{tabular}{|c|c|c|}
\hline Kelompok vs & Kelompok & p-value \\
\hline \multirow{3}{*}{ DMSO } & 20 & 0,0369 \\
\cline { 2 - 3 } & 40 & 0,0369 \\
\cline { 2 - 3 } & Ampisilin & 0,0369 \\
\hline \multirow{2}{*}{20} & 40 & $0.2752^{*}$ \\
\hline 40 & Ampisilin & 0.04953 \\
\hline & Ampisilin & 0.04953 \\
\hline
\end{tabular}

Ket: $*=$ p-value $<0,05$, data tidak berbeda signifikan.
Zona hambat yang dihasilkan dianalis menggunakan program $\mathrm{R}$ versi 3.0.3 dengan metode uji Kruskal Wallis. Nilai p-value hasil uji beda dengan Kruskal Wallis terdapat pada tabel 3. Hasil uji beda menunjukkan bahwa terdapat perbedaan yang signifikan pada kedua variasi konsentrasi fraksi n-heksan dengan kontrol negatif ini menyatakan bahwa sampel memiliki aktivitas antibakteri. Namun zona hambat yang dihasilkan oleh fraksi n-heksan kulit buah naga merah tidak sebaik kontrol positifnya yaitu ampisilin karena kedua konsentrasi berbeda signifikan dengan ampisilin. Konsentrasi $20 \mathrm{mg} / \mathrm{mL}$ dan $40 \mathrm{mg} / \mathrm{mL}$ tidak memiliki perbedaan yang signifikan sehingga dapat diasumsikan bahwa penggunaan konsentrasi $20 \mathrm{mg} / \mathrm{mL}$ sudah dapat digunakan sebagai antibakteri karena memiliki aktivitas antibakteri yang sama dengan konsentrasi $40 \mathrm{mg} / \mathrm{mL}$.

Beberapa senyawa pada fraksi n-heksan yang diduga memiliki aktivitas antibakteri berdasarkan hasil skrining fitokimia adalah alkaloid, steroid dan triterpenoid. Penelitian Luo juga menyatakan bahwa kulit buah naga merah mengandung $\beta$-amirin (15.87\%), $\alpha$-amirin (13.90\%), octacosane $(12.2 \%), \gamma$ sitosterol (9.35\%), octadecane $(6.27 \%)$, tetracosanol $(5.19 \%)$, sitostenone $(4.65 \%)$, dan campesterol $(4.16 \%)$ yang sebagian besar senyawa tersebut tergolong senyawa triterpenoid dan steroid (Luo, 2014 ).

Mekanisme kerja alkaloid sebagai antibakteri diprediksi melalui penghambatan sintesis dinding sel yang akan menyebabkan lisis pada sel sehingga sel akan mati (Lamothe dkk, 2009). Menurut Cowan steroid dapat berinteraksi dengan membran fosfolipid sel yang bersifat impermeabel terhadap senyawasenyawa lipofilik sehingga menyebabkan integritas membran menurun, morfologi membran sel berubah, dan akhirnya dapat menyebabkan membran sel rapuh dan lisis. Triterpenoid dapat bereaksi dengan protein transmembran pada membran luar dinding sel bakteri, membentuk ikatan polimer yang kuat sehingga mengakibatkan rusaknya porin. Rusaknya porin yang merupakan pintu keluar masuknya senyawa akan mengurangi permeabilitas dinding sel bakteri yang akan mengakibatkan sel bakteri akan kekurangan nutrisi, sehingga pertumbuhannya akan terhambat atau mati.

\section{KESIMPULAN}

Fraksi n-heksan kulit buah naga merah mengandung senyawa alkaloid, steroid, triterpenoid dan flavonoid. Fraksi n-heksan kulit buah naga merah memiliki aktivitas antibakeri pada bakteri Staphylococcus aureus. Konsentrasi hambat minimum (KHM) fraksi n-heksan kulit buah naga 
merah terhadap Staphylococcus aureus adalah 625 ppm dengan zona hambat $17 \mathrm{~mm}$.

\section{Terima Kasih}

Ucapan terima kasih disampaikan kepada laboratorium bakteri jurusan analis kesehatan Politeknik Kesehatan Kalimantan Barat karena telah mengizinkan kami untuk melakukan penelitian di laboratorium tersebut.

\section{DAFTAR PUSTAKA}

1. Departemen Kesehatan RI. 1988. Inventaris Obat Indonesia Jilid I. Badan Penelitian dan Pengembangan Kesehatan, Jakarta.

2. Melliawati, Ruth. 2009. Esherichia coli dalam Kehidupan Manusia. BioTrend.4(1).

3. Kaper, JB., Nataro, J.P dan Mobley, H.L. Pathogenic Staphylococcus aureus. Nat. Rev. Microbiol. 2:123-140

4. Luo, H., Cai, Y., Peng, Z., Liu, T dan Yang, S. 2014. Chemical Composition and In Vitro Evaluation of The Cytotoxic and Antioxidant Activities of Supercritical Carbon Dioxide Extracts of Pitaya (Dragon Fruit) Peel. Chem. Central J.8(1):2-7.

5. Guarrera, P.M. 2005. Traditional phytotherapy in Central Italy (Marche, Abruzzo, and Latium). Fitoterapia.76(1):1-25.

6. Ahmad, I dan Aqil, F. 2007. In vitro efficacy of bioactive extracts of 15 medicinal plants against ES $\beta L$-producing multidrug-resistant enteric bacteria. Microbiological Research.162(3):264275.

7. Barbour, E.K., Al Sharif, M. Dan Sagherian, V.K. 2009. Screening of selected indigenous plants of Lebanon for antimicrobial activity. Journal of Ethnopharmacology.93(1):1-7.

8. Kristianto, D. 2008. Buah Naga Pembudidayaan di Pot dan di Kebun. Penebar Swadaya, Jakarta.

9. Warisno, Dahana K. 2010. Cara Pintar Bertanaman Buah Naga di Kebun, Pekarangan dan dalam Pot. PT. Gramedia Pustaka Utama, Jakarta.

10. Latif, A.Z., Haque, M. dan Shanmugasundaram, C. 2012. Clinical study of preventive potentials of consumption of Buah naga [Cactaceae] against paracetamol-induced hepatotoxicity as well as the other associated biological effects. Asian J. Res. in Pharmaceutical Sciences.2(1):16-23.

11. Wu, L., Hsu, H., Chen, Y., Chiu, C., Lin, Y. dan Ho, J.A. 2006. Antioxidant and antiproliferative activities of red pitaya. J. Food Chem.95(2):319327.

12. Khalili, M.A., Norhayati, A.H., Rokiah, MY., Asmah, R., Muskinah, M.S. dan Manaf, A.A. Hypocholesterolemic Effect of Red Pitaya (Hylocereus sp.) on Hypercholesterolemia Induced Rats. Int. Food Res. J. 16:431-440.

13. Nurmahani, M.M., Osman, A., Abdul Hamid, A., Mohamad Ghazali, F. dan Pak Dek, M.S. Short Communication Antibacterial Property of Hylocereus polyrhizus and Hylocereus undatus Peel Extracts. Int. Food Res. J. 2012;19(1):7784.

14. Indian Council of Medical Research. 2009. Detection of Antimicrobial Resistance in Common Gram Negative and Gram Positive Bacteria Encountered in Infectious deseases- An Update. ICMR Bulletin.39:1-3.

15. Lamothe, R.G., Mitchell, G., Gattuso, M., Diarra, M.S. dan Malouin, F. 2009. Plant Antimicrobial Agents and Their Effects on Plant and Human Pathogens. International Journal of Molecular Sciences. 10:3400-3419. 